\title{
TEACHERS' EXPERIENCES AND PRACTICES WITH GAME-BASED LEARNING
}

\author{
A. Martins, L. Oliveira \\ University of Minho, Institute of Education (PORTUGAL)
}

\begin{abstract}
Game-based learning can support effective pedagogical approaches that can only enter schools if teachers are on-board with it, and are given the necessary time, training and tools. This research examines teachers' perceptions about educational games and the use of video games in their teaching practice.

Data was collected through a survey conducted at the beginning of a continuous professional development course about the creation of educational games, for elementary and middle school teachers. The responses from eighteen teachers working in a group of schools located in the northern region of Portugal are analysed and presented in this paper.

Teachers have a low perception of their own technological knowledge and rarely use video games in their teaching practices. Lack of technological resources, as well as insufficient time, are the barriers more referred to as limiting the implementation of game-based learning approaches in schools.
\end{abstract}

The data presented in this study is relevant to guide the design of training programs and strategies to support and scaffold teachers' knowledge and practical application of game-based learning.

Keywords: Game-based Learning, Teacher Training, TPACK, Teacher Perceptions.

\section{INTRODUCTION}

There are several studies identifying benefits of using video games for learning, highlighting positive impacts on learning, motivation and engagement [1]. Games can be used in education in many ways. Holmes and Gee categorize those practices into four main groups: action frame, structuring frame, bridging frame and design frame [2]. One particularly interesting practice of game-based learning is game design [3], a frame that focus on the creation process, "to promote the learner to a designer of games and game-related artefacts and experiences" [2] (Holmes \& Gee, 2016).

Challenging students to design games that incorporate specific contents of the curriculum is a powerful pedagogical strategy [3] that can only enter schools with the support of teachers. But for that to happen, it is necessary that they have time, training, resources, and most importantly, they need to find it valuable. Having that into account, we've developed a training course for teachers on the subject of creation of educational video games [4].

Interestingly, designing educational video games is well aligned with the Technological Pedagogical Content Knowledge theoretical framework (TPACK) that describes the types of knowledge necessary for the integration of technology into the teaching practice [5]. This model focuses on the importance of developing and integrating knowledge of content, pedagogy and technology. In the creation of educational video games, technological tools are approached and the pedagogical potential of video games is addressed, which, having specific learning objectives, thus also integrate the particular content knowledge of the teachers.

During this continuous professional development course, we've examined teachers' experiences of learning through educational video game design, with results being published later on this year. In this paper we present findings from a survey conducted at the beginning of the course, in 2017, with the following objectives: 1 . investigating teachers' familiarity with video games, 2 . understanding teachers' attitudes toward game-based learning, 3. uncovering teachers' perceptions of effectiveness in the adoption of video games for teaching, in terms of TPACK, and 4. exploring challenges and barriers to the integration of video games in education. 


\section{METHODOLOGY}

A survey was created with the objective of obtaining initial information about teachers' practices, experiences and expectations regarding the use of video games in education. The survey is organized in five sections and its contents and structure are shown in Table 1.

Table 1. Structure of the survey applied to the participating teachers

\begin{tabular}{|c|c|c|c|c|}
\hline Section & Category & Item & Description & $\begin{array}{c}\text { Type of } \\
\text { Question }\end{array}$ \\
\hline \multirow{6}{*}{$\begin{array}{l}\text { Sociodemographic } \\
\text { and professional } \\
\text { information }\end{array}$} & \multirow{2}{*}{$\begin{array}{l}\text { Characterization } \\
\text { (personal) }\end{array}$} & 2 & Age. & Open \\
\hline & & 3 & Sex. & Closed \\
\hline & \multirow{4}{*}{$\begin{array}{l}\text { Characterization } \\
\text { (professional) }\end{array}$} & 4 & Professional situation. & Closed \\
\hline & & 5 & Years of service. & \multirow{2}{*}{ Open } \\
\hline & & 6 & Discipline(s). & \\
\hline & & 7 & K-12 stage(s). & Closed \\
\hline \multirow{9}{*}{$\begin{array}{l}\text { Experience of using } \\
\text { video games }\end{array}$} & \multirow{3}{*}{ Practices (personal) } & 8 & Frequency with which you play video games. & Closed \\
\hline & & 9 & If you never play, please explain briefly why. & \multirow{2}{*}{ Open } \\
\hline & & 10 & Indicate up to 3 video games you enjoy playing. & \\
\hline & Knowledge & 11 & List up to 3 educational video games you know. & Open \\
\hline & \multirow{5}{*}{ Practices (professional) } & 12 & Have you ever used video games in your teaching practice? & \multirow{2}{*}{ Closed } \\
\hline & & 13 & If yes, with what purpose? & \\
\hline & & 14 & Briefly describe the experience & Open \\
\hline & & 15 & How often do you use video games in your teaching practice? & Closed \\
\hline & & 16 & Indicate which videogames you have already used in your teaching practice & Open \\
\hline \multirow{2}{*}{$\begin{array}{l}\text { Attitudes towards the } \\
\text { use of video games } \\
\text { in education }\end{array}$} & \multirow[b]{2}{*}{ Motivation } & 17 & Why are you interested in learning about educational video games? & \multirow[b]{2}{*}{ Closed } \\
\hline & & 18 & $\begin{array}{l}\text { What do you think is the probability of incorporating video-game-based learning into your teaching } \\
\text { practice? }\end{array}$ & \\
\hline \multirow{30}{*}{$\begin{array}{l}\text { Self-perception of } \\
\text { effectiveness } \\
\text { in the adoption } \\
\text { of video games } \\
\text { for teaching }\end{array}$} & \multirow{6}{*}{$\begin{array}{l}\text { Technological } \\
\text { Knowledge (TK) }\end{array}$} & 19.1 & I know how to solve my own technical problems with regards to technology and video games. & \multirow{6}{*}{$\begin{array}{l}\text { Likert } \\
\text { Scale }(5 \\
\text { points) }\end{array}$} \\
\hline & & 19.2 & I can learn about video games easily. & \\
\hline & & 19.3 & I keep track of important new video games for teaching and learning. & \\
\hline & & 19.4 & I often explore / experiment with video games. & \\
\hline & & 19.5 & I know a range of different video games. & \\
\hline & & 19.6 & I have the technical skills I need to use video games. & \\
\hline & \multirow{3}{*}{$\begin{array}{l}\text { Content Knowledge } \\
\text { (CK) }\end{array}$} & 20.1 & I have enough knowledge about the curricular area(s) I teach. & \multirow{3}{*}{$\begin{array}{l}\text { Likert } \\
\text { Scale }(5 \\
\text { points) }\end{array}$} \\
\hline & & 20.2 & I can use a thought form appropriate to the curricular area(s) I teach. & \\
\hline & & 20.3 & I have several ways and strategies to develop my understanding of the curricular area(s) I teach. & \\
\hline & \multirow{7}{*}{$\begin{array}{c}\text { Pedagogical } \\
\text { Knowledge (PK) }\end{array}$} & 21.1 & I know how to evaluate student performance in a video game-based class. & \multirow{7}{*}{$\begin{array}{l}\text { Likert } \\
\text { Scale }(5 \\
\text { points) }\end{array}$} \\
\hline & & 21.2 & $\begin{array}{l}\text { I can adapt the kind of teaching I teach based on what the students understand or do not } \\
\text { understand at a given moment in a video game-based class. }\end{array}$ & \\
\hline & & 21.3 & I can adapt my teaching style to different students in a video game-based class. & \\
\hline & & 21.4 & I can assess students' learning in a variety of ways in a video game-based class. & \\
\hline & & 21.5 & I can use a wide range of pedagogical strategies in the context of a video game-based class. & \\
\hline & & 21.6 & $\begin{array}{l}\text { I am familiar with the most common perceptions and learning difficulties of students in a video } \\
\text { game-based class. }\end{array}$ & \\
\hline & & 21.7 & I know how to organize and maintain classroom management in a video game-based class. & \\
\hline & $\begin{array}{l}\text { Pedagogical Content } \\
\text { Knowledge (PCK) }\end{array}$ & 22 & $\begin{array}{l}\text { I can select effective pedagogical strategies to guide the students' thinking and learning in the } \\
\text { curricular area(s) I teach. }\end{array}$ & $\begin{array}{c}\text { Likert } \\
\text { Scale } \\
\text { (5 points) } \\
\end{array}$ \\
\hline & $\begin{array}{l}\text { Technological Content } \\
\text { Knowledge (TCK) }\end{array}$ & 23 & $\begin{array}{l}\text { I know games that I can use to facilitate the understanding and execution of activities in the } \\
\text { curricular area(s) I teach. }\end{array}$ & $\begin{array}{l}\text { Likert } \\
\text { Scale }(5 \\
\text { points) }\end{array}$ \\
\hline & \multirow{9}{*}{$\begin{array}{c}\text { Technological } \\
\text { Pedagogical } \\
\text { Knowledge (TPK) }\end{array}$} & 24.1 & I can choose videogames that reinforce the pedagogical strategies selected for a class. & \multirow{9}{*}{$\begin{array}{l}\text { Likert } \\
\text { Scale }(5 \\
\text { points) }\end{array}$} \\
\hline & & 24.2 & I can choose the video games to use in a class to improve student learning. & \\
\hline & & 24.3 & $\begin{array}{l}\text { My professional background has made me think more deeply about how video games can } \\
\text { influence the pedagogical strategies I use in the classroom. }\end{array}$ & \\
\hline & & 24.4 & I think critically about how to use video games in the classroom. & \\
\hline & & 24.5 & I can adapt the use of video games to different teaching-learning activities. & \\
\hline & & 24.6 & $\begin{array}{l}\text { I can select video games, to use with the students, to improve what I teach, how to teach and } \\
\text { what they learn. }\end{array}$ & \\
\hline & & 24.7 & I can use strategies, with students, that combine content, video games and pedagogy. & \\
\hline & & 24.8 & $\begin{array}{l}\text { I can demonstrate leadership in assisting colleagues in the school and / or district where I teach in } \\
\text { the coordination of content use, video games, and pedagogical strategies. }\end{array}$ & \\
\hline & & 24.9 & I can choose video games that improve / facilitate / enhance the content of a lesson. & \\
\hline & \multirow{3}{*}{$\begin{array}{l}\text { Technological } \\
\text { Pedagogical Content } \\
\text { Knowledge (TPACK) }\end{array}$} & 25.1 & $\begin{array}{l}\text { I can determine how videogames combine the curricular area(s) I teach, technology, and } \\
\text { pedagogical strategies. }\end{array}$ & \\
\hline & & 25.2 & I can redirect a videogame for educational use. & $\begin{array}{l}\text { Scale }(5 \\
\text { points) }\end{array}$ \\
\hline & & 25.3 & I can determine the strengths and limitations of a video game to teach specific content. & \\
\hline $\begin{array}{l}\text { Challenges to the } \\
\text { integration of video } \\
\text { games in education }\end{array}$ & Limitations & 26 & What are the major barriers teachers face in using video games for teaching? & Closed \\
\hline
\end{tabular}


Section 1 of the survey gathers sociodemographic and professional information in order to characterize the participant teachers. Section 2 inquires teachers about their experience in using video games, and was created based on the work of Takeuchi and Vaala [6]. Section 3 addresses attitudes towards the use of video games in education, and was inspired by the work of Wu [7]. Section 4 asks teachers about their perceptions of effectiveness in the adoption of video games for teaching, and was built based on the work of Hsu and colleagues [8]. Finally, section 5 addresses the challenges and barriers to the integration of video games in education, and the question used was adapted from Takeuchi and Vaala's survey [6].

Participants in this study are elementary and middle school teachers from a group of schools located in the district of Braga, in a northern region of Portugal. Twenty teachers registered initially for the continuous professional development course, eleven of which finished the training program. The survey was disseminated in digital format (through a Google form) and completed during the first session of the course.

This survey was validated by two external teachers (from K-12 and higher education educational stages). Not having been previously applied with a test group, it was decided to include an evaluation section of the survey as its integral part. Thus, in item 27, teachers had to indicate their degree of agreement on a five-point Likert scale (1 - I strongly disagree to 5 - I strongly agree), regarding the clarity of the survey and the degree of their understanding of the questions. The survey was answered by 18 teachers, and its evaluation is presented in Table 2 .

Table 2. Evaluation of the survey by the participant teachers

\begin{tabular}{|l|c|c|}
\hline Item of the Survey - Likert Scale (5 points) & Mean & $\begin{array}{c}\text { Standard } \\
\text { deviation }\end{array}$ \\
\hline The survey is clear. & 3,8 & 3,1 \\
\hline The survey is not too long. & 3,4 & 3,1 \\
\hline I understood the questions in the section "Experience of using video games" & 3,6 & 3,6 \\
\hline I understood the questions in the section "Attitudes towards the use of video games in education". & 3,6 \\
\hline $\begin{array}{l}\text { I understood the questions in the section "Self-perception of effectiveness in the adoption of video } \\
\text { games for teaching". }\end{array}$ & 3,6 \\
\hline I understood the questions in the section "Challenges to the integration of video games in education". & 3,8 \\
\hline
\end{tabular}

It is considered that the evaluation of this instrument was positive, and that, in general, teachers found the survey clear and understood the questions, so we find ourselves confident to use its results.

\section{RESULTS}

In this section the results are shown based on the answers of the 18 respondent teachers.

Table 3 presents the participants' personal and professional characterization. $61 \%$ of the participants are female, $33 \%$ have between 41 and 45 years old of age, and the majority are middle school teachers. Most participants are teaching either Mathematics or Portuguese and have taught numerous years before, with $39 \%$ having between 21 and 25 years of service in the teaching profession. 
Table 3. Sociodemographic and professional characterization of the participants

\begin{tabular}{|c|c|c|c|}
\hline Sex & $\%$ & Years of service & $\%$ \\
\hline Male & 38,9 & $6-10$ years & 5,6 \\
\hline Female & 61,1 & $11-15$ years & 16,7 \\
\hline Total & 100 & $16-20$ years & 27,8 \\
\hline Age & $\%$ & $21-25$ years & 38,9 \\
\hline $36-40$ years & 16,7 & $26-30$ years & 5,6 \\
\hline $41-45$ years & 33,3 & 31-35 years & 0,0 \\
\hline $46-50$ years & 16,7 & $36-40$ years & 5,6 \\
\hline $51-55$ years & 27,8 & Total & 100 \\
\hline $56-60$ years & 0,0 & Discipline & $\%$ \\
\hline $61-65$ years & 5,6 & Mathematics & 27,8 \\
\hline Total & 100 & Portuguese & 16,7 \\
\hline $\mathrm{K}-12$ stage & $\%$ & Portuguese, French & 5,6 \\
\hline Elementary school & 27,8 & Mathematics, Natural Sciences & 11,1 \\
\hline Middle school ( $5^{\text {th }}$ and $6^{\text {th }}$ grade $)$ & 33,3 & $\begin{array}{l}\text { Portuguese, Mathematics, Expressions, } \\
\text { Study of the Environment, Citizenship }\end{array}$ & 27,8 \\
\hline Middle school ( $7^{\text {th }}$ to $9^{\text {th }}$ grade $)$ & 22,2 & Spanish & 5,6 \\
\hline Middle school $\left(7^{\text {th }}\right.$ to $9^{\text {th }}$ grade), High school & 16,7 & Portuguese, History and Geography of Portugal & 5,6 \\
\hline Total & 100 & Total & 100 \\
\hline
\end{tabular}

At the beginning of the course teachers were asked about their motivations to participate; they could choose more than a motive as an answer. $25 \%$ of all responses felled under the category "to increase student motivation and engagement", while $16 \%$ of responses were related to the need "to obtain credits", so we can see that there can be very different motivations to attend a course like this, with internal and external focuses and goals, as illustrated by Figure 1.

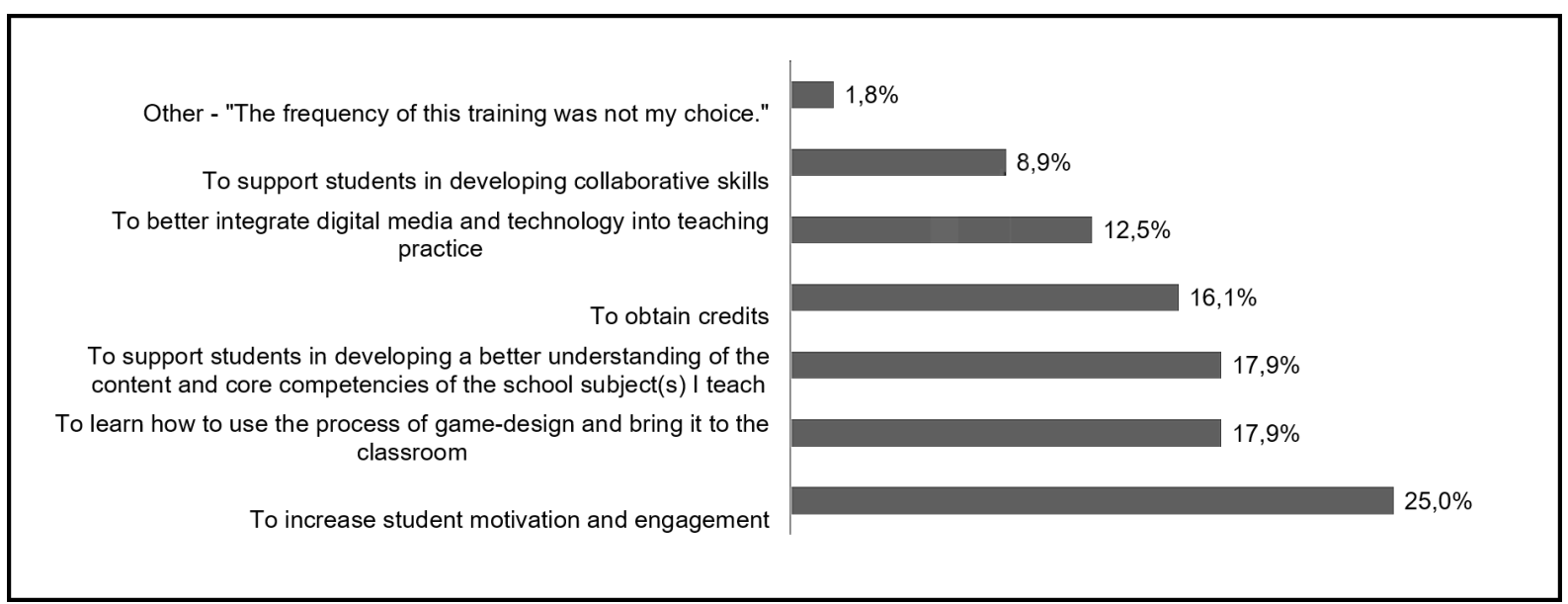

Figure 1. Motivations to participate in the course.

Figure 2 presents the frequency with which teachers play video games, showing that about a third of the participants said they never play video games. This lack of familiarity with video games will probably be reflected on their attitude and confidence in using game-based learning strategies in their teaching practice. 


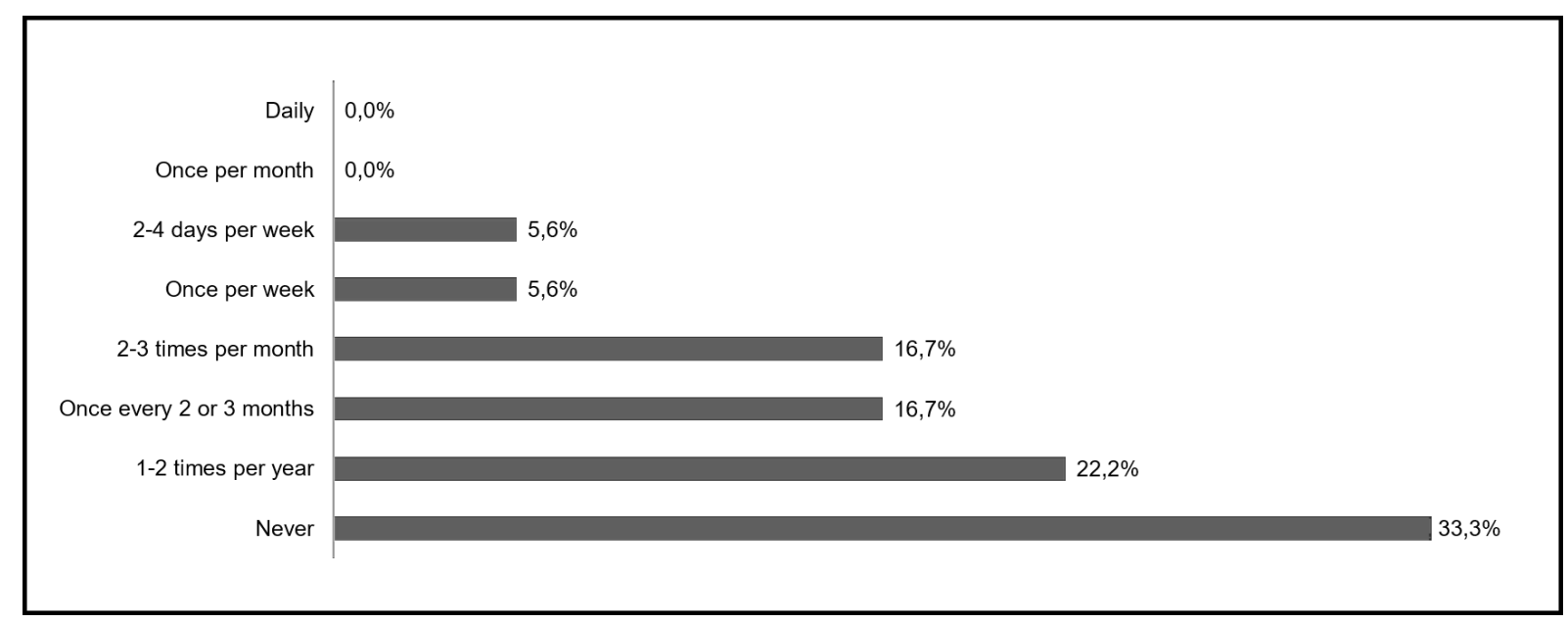

Figure 2. Frequency with which teachers play video games

Table 4 presents the specific video games teachers play, as well as the educational video games that they are aware of. It is interesting to note that $39 \%$ of the participants say they don't know any video game with learning goals.

Table 4. Video games teachers play and educational video games they know

\begin{tabular}{|ll|ll|}
\hline Video games you play & N & Educational video games you know & N \\
\hline Candy Crush & 3 & Do not know any & 9 \\
"Little Witch" ("Bruxinha") & 1 & Do not remember / Do not know the names & 2 \\
Bubble Witch 2 & 1 & SuperTmatick & 2 \\
SimCity / SimCity Buildit & 2 & Games from "Virtual School" ("Escola Virtual") & 2 \\
GTA v & 1 & Games of 20 - Digital Classroom & 1 \\
SuperTmatik & 1 & Dominoes Merge - Block Puzzle & 1 \\
Dominoes Merge - Block Puzzle & 1 & Brain It On! - Physics Puzzles & 1 \\
Brain It On! - Physics Puzzles & 1 & Game of Sticks (Jogo dos Palitos) & 1 \\
Game of Sticks (Jogo dos Palitos) & 1 & Game of 24 - online & 1 \\
Pacman & 1 & Ouri - online & 1 \\
Farm Heroes Saga & 1 & Hill Climb Racing & 1 \\
Solitaire & 1 & BBTAN & 1 \\
Hearts & 1 & & \\
Ouri & 1 & & \\
1010 & 1 & & \\
Tetris & 1 & & \\
Hill Climb Racing & 1 & & \\
BBTAN & 1 & & \\
Games from "Virtual School" and "Digital Classroom" & 1 & & \\
\hline Total & $\mathbf{2 2}$ & Total & \\
\hline
\end{tabular}

When asked about the integration of video games into classrooms, $72 \%$ of teachers answered they had never used a video game in any form in their teaching practice. Table 5 presents supplementary answers from teachers that had previously used video games in their classrooms, describing the purpose of the use, the experience, as well as the frequency of utilization of video games in class, and the names of the particular games these teachers have used. 
Table 5. Cases of video game integration into the participants' teaching practices

\begin{tabular}{|c|c|c|c|c|}
\hline ID & With what purpose? & Briefly describe the experience. & $\begin{array}{l}\text { How often do you use } \\
\text { video games in class? }\end{array}$ & $\begin{array}{l}\text { Indicate which videogames you have } \\
\text { already used in your teaching practice. }\end{array}$ \\
\hline A & $\begin{array}{l}\text { Engage/create } \\
\text { connections with a } \\
\text { concept difficult to } \\
\text { understand }\end{array}$ & $\begin{array}{l}\text { Facilitated students' motivation and } \\
\text { understanding. }\end{array}$ & Once or twice a year & SuperTmatick and some apps/games \\
\hline B & $\begin{array}{l}\text { Introduce a new } \\
\text { concept }\end{array}$ & $\begin{array}{l}\text { It is always a very appealing activity } \\
\text { for students. }\end{array}$ & At least once a week & $\begin{array}{l}\text { Videos of the resources presented in the } \\
\text { Digital Classroom and Virtual School }\end{array}$ \\
\hline c & $\begin{array}{l}\text { Oral comprehension; } \\
\text { vocabulary }\end{array}$ & $\begin{array}{l}\text { Very positive ... however, the fact } \\
\text { that the Internet is very slow in } \\
\text { classrooms ends up hampering an } \\
\text { activity that students so much enjoy. }\end{array}$ & Once or twice a year & $\begin{array}{l}\text { Games from Virtual School, Digital } \\
\text { Classroom and Kahoot platform }\end{array}$ \\
\hline D & Practice/review & & Once per school term & $\begin{array}{l}\text { Ouri - online, Game of } 24 \text { - online, } \\
\text { superTmatik }\end{array}$ \\
\hline $\mathrm{E}$ & Practice concepts & $\begin{array}{l}\text { Students show willingness to } \\
\text { practice. }\end{array}$ & Once or twice a year & Don't remember \\
\hline
\end{tabular}

Figure 3 presents what teachers perceived, before the professional development training course, as the probability of incorporating video-game-based learning into their teaching practices in the nearby future, showing that $72 \%$ considered likely to do so.

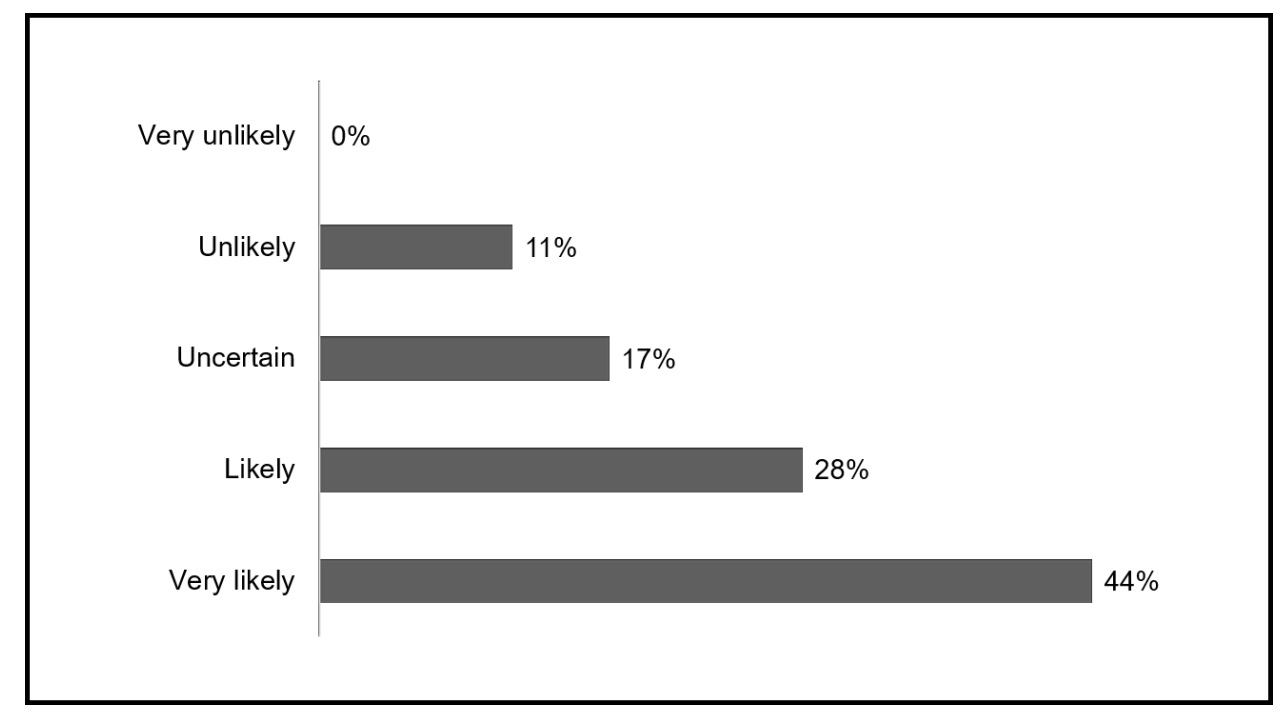

Figure 3. Perceived probability of using video game-based learning in the future

In terms of barriers to adopt game-based learning, the most recognized by these teachers were lack of technological resources and insufficient time. Not enough knowledge about technology and about games were also strongly represented amongst the challenges to integration. None of the participants considered the lack of support from parents to be a barrier. Likewise, none considered the inexistence of barriers as being true. 


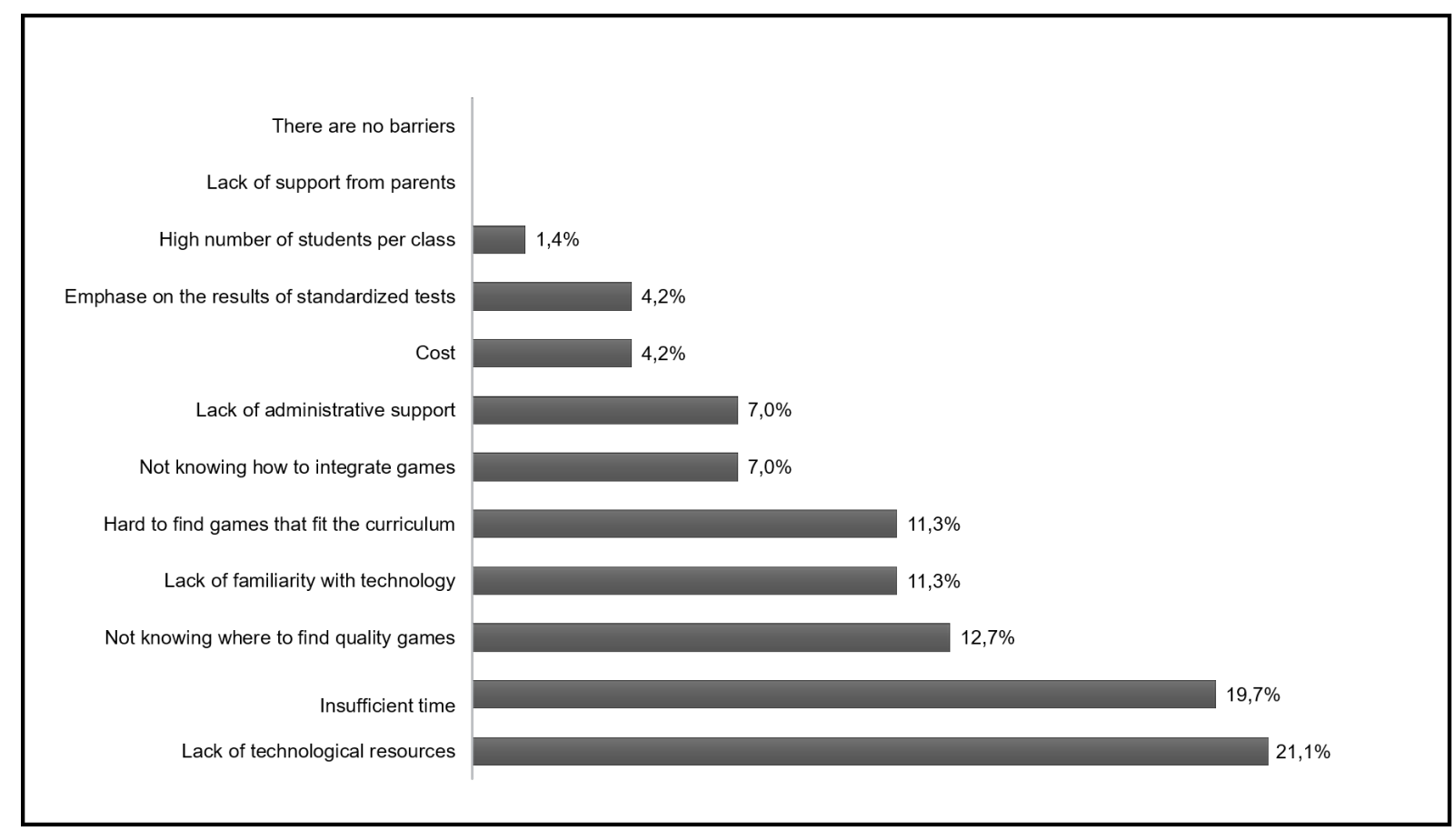

Figure 4. Barriers to the use of game-based learning in schools.

Regarding teachers' perceptions of their TPACK competence, related to effectiveness in the adoption of video games for teaching, the mean value is low, 0.07 , with a standard deviation of 0.73 . These are values in a scale from -2 to 2 , since we converted the 5-point Likert scale of agreement, from 1, 2, 3, 4,5 to $-2,-1,0,1,2$ scores, to help with visualization, and to highlight if the participants' selfevaluation is negative (disagreement) or positive (agreement).

Figure 5 presents the mean values by TPACK dimension. We can see the lower value is related to technological knowledge, and the higher value regards content knowledge, with teachers showing confidence in scientific knowledge about the subjects they teach.

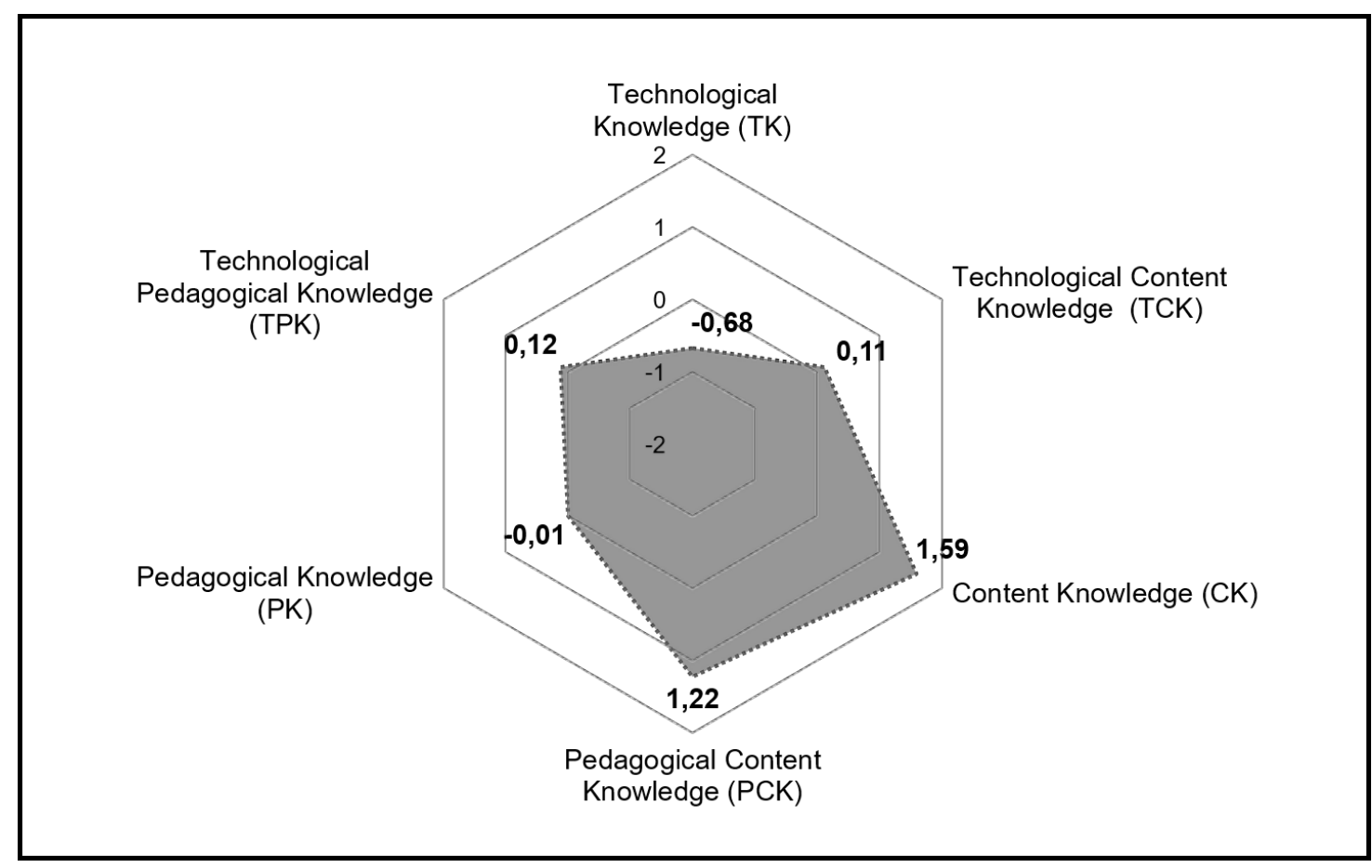

Figure 5. Teachers' perceptions of TPACK competence. 
It may be interesting to note that while the dimension "pedagogical content knowledge" has a high value, the dimension "pedagogical knowledge" as a low value. This might indicate that while teachers feel assured about pedagogical knowledge related to their specific content areas, they might feel less confident regarding pedagogy in a broader scope.

\section{CONCLUSIONS}

This paper presents the conception and implementation of a survey to investigate teachers' experiences and perceptions on the use of game-based learning, and analyses the responses of eighteen teachers, collected during the beginning of a continuous professional development course on the subject of educational video game creation.

It is important to understand that there are very different motivations to attend courses like this one, which needs to be taken into account while developing future teacher training courses, as to stimulate and maintain the participants' interest and drive, combating the high rates of withdrawal (in the present case corresponding to $45 \%$ ). Studying further this significant aspect of teacher training is required.

Teachers' familiarity with video games is low and it is only natural that this leads to small rates of integration of video games in schools, and less confidence in using game-based learning strategies. From the collected data we see that it is imperative to expand teachers' knowledge of good educational video games that fit curricular needs and to make it easier for them to understand where to find quality games and how to integrate them into their practices.

The few teachers that had already used video games with a teaching purpose describe positively the experience, highlighting internet access as a barrier to its further use. Indeed, lack of technological resources and knowledge, as well as insufficient time, are the most common barriers stated, limiting the implementation of game-based learning approaches in schools.

In general, teachers rate highly their intentions to use video-game-based learning. We think it would be curious to do a follow-up and investigate if those intentions change over time and if they are actually executed.

Teachers have a low perception of their own technological knowledge and are not used to incorporating video games in their teaching practices. There is a need to increase knowledge about the technology and the pedagogy associated with games, thus justifying the existence of training courses as the one developed by us, as well as others. It is important though to make them accessible and appealing to a greater number of teachers, possibly even integrating them into pre-service education.

It would be interesting to see if the participants' answers changed after finishing the course, particularly regarding TPACK perceptions, and that is something we will keep working on.

We believe the data collected, though from a small sample, is relevant and, particularly after applying this survey to a larger sample, can guide the design of training programs and strategies to support and scaffold teachers' knowledge and practical application of game-based learning.

\section{ACKNOWLEDGEMENTS}

This work is funded by CIEd-Research Centre on Education, projects UID/CED/1661/2013 and UID/CED/1661/2016, Institute of Education, University of Minho, through national funds of FCT/MCTES-PT. The first author is funded by FCT/MCTES-PT with a doctoral grant within the PhD Program Technology Enhanced Learning and Societal Challenges, supported by Fundação para a Ciência e Tecnologia, FCT I. P. - Portugal, under the contract PD/BD/127783/2016. The second author is also funded by FCT/MCTES-PT, sabbatical grant SFRH/BSAB/135571/2018.

\section{REFERENCES}

[1] Connolly, T. M., Boyle, E. A., MacArthur, E., Hainey, T., \& Boyle, J. M. (2012). A systematic literature review of empirical evidence on computer games and serious games. Computers \& Education, 59(2), 661-686.

[2] Holmes, J. B., \& Gee, E. R. (2016). A framework for understanding game-based teaching and learning. On the horizon, 24(1), 1-16. 
[3] Kafai, Y. B., \& Burke, Q. (2015). Constructionist gaming: Understanding the benefits of making games for learning. Educational psychologist, 50(4), 313-334.

[4] Martins, A. R., \& Oliveira, L. R. (2018, June). Students as Creators of Educational GamesLearning to Use Simple Frameworks and Tools to Empower Students as Educational Game Designers. In EdMedia+ Innovate Learning (pp. 1210-1215). Association for the Advancement of Computing in Education (AACE).

[5] Mishra, P., \& Koehler, M. J. (2006). Technological pedagogical content knowledge: A framework for teacher knowledge. Teachers college record, 108(6), 1017.

[6] Takeuchi, L. M., \& Vaala, S. (2014). Level up learning: A national survey on teaching with digital games. New York: The Joan Ganz Cooney Center at Sesame Workshop.

[7] Wu, M. L. (2015). Teachers' experience, attitudes, self-efficacy and perceived barriers to the use of digital game-based learning: A survey study through the lens of a typology of educational digital games. Michigan State University. Educational Psychology and Educational Technology.

[8] Hsu, C.-Y., Tsai, M.-J., Chang, Y.-H., \& Liang, J.-C. (2017). Surveying In-Service Teachers' Beliefs about Game-Based Learning and Perceptions of Technological Pedagogical and Content Knowledge of Games. Educational Technology \& Society, 20 (1), 134-143. 